\title{
Management Practices and Performance Improvement in Manufacturing Enterprises: The Case of Kaizen Adoption in Ghana
}

\author{
Charles Godfred Ackah, Richmond Atta-Ankomah, \\ and Johnson Appiab Kubi
}

\section{INTRODUCTION}

There seem to be no controversy about the importance of industrialization for sustained growth and employment generation for developing economies. Interestingly, Rodrik (2015) argues that in spite of efforts at industrialization, sub-Saharan African (SSA) countries, with the exception of Mauritius, have suffered significant deindustrialization, whereas some of their Asian counterparts have experienced significant growth in manufacturing value added. It appears the industrial successes of these Asian countries, particularly in the case of China, are highly associated with expansion in both public and private investments in innovation capabilities, including managerial capacity (Kim 2014; Fu 2015; Bell and Pavitt 1997). Managerial capacity is particularly crucial for competitiveness in

C. G. Ackah $(\bowtie) \bullet$ R. Atta-Ankomah

Institute of Statistical, Social and Economic Research, University of Ghana, Accra, Ghana e-mail: cackah@ug.edu.gh

J. Appiah Kubi

Department of Economics, University of Ghana, Accra, Ghana

(C) The Author(s) 2020

A. Hosono et al. (eds.), Workers, Managers, Productivity, https://doi.org/10.1007/978-981-15-0364-1_12 
the global economy (Bruhn and Zia 2013; Higuchi et al. 2015). Meanwhile, innovation and managerial capacity in Africa is comparatively low (Diop 2017) and there are a host of constraints affecting innovation in SSA, particularly firm-level innovation (Egbetokun et al. 2016). Consequently, limited innovation and managerial capabilities may constitute a key missing link in the industrialization puzzle for many SSA countries including Ghana.

Ghana's industrialization attempts date back to the early 1960s, at a time when the country's gross domestic product (GDP) per capita was equivalent to those of Malaysia and Korea. Today, Korea's GDP per capita is nearly 19 times that of Ghana, whereas Malaysia's GDP per capita is over 6 times that of Ghana (World Bank WDI online). Like many other countries in SSA, the industrialization drive in Ghana was initially being pushed through import substitution (IS) policies, meant to protect local infant industries that were mainly state owned. In the wake of a significant and continuous economic downturn in the 1970s and 1980s, the IS policy was replaced in the early 1980s with an export-oriented industrialization policy which was a component of a gamut of policies adopted under the World Bank's structural adjustment program (SAP). The change in policy however only came with a brief period of recovery particularly with regard to industrial growth, dashing off renewed hopes for a major takeoff in industrial development in Ghana. Data from the World Bank's World Development Indicators (WDI) online indicate that the value added of manufacturing and industry declined from the mid-1960s up to the early 1980s, after which a brief period of recovery ensued. Between the mid1980s and the mid-2000s, manufacturing value added remained stymied while it has fallen continuously from the mid-2000s onward. Currently, the Ghana government has instituted a policy to establish a factory in each administrative district, in what has been dubbed "One District One Factory" program, to drive the country's industrialization agenda.

While Ghana still awaits a takeoff in industrial development, there has been a structural transformation, characterized by a leapfrogging of the manufacturing sector particularly with respect to the pattern and trends in labor movement across the major economic sectors. Available statistics from the Ghana Statistical Service $(2013,2015)$ show that agricultural sector's share in employment has declined while the services sector now accounts for the largest share in employment with no major change in the employment shares for industry and manufacturing sectors. The data, however, show that the majority of people in the services sector who may have moved from agriculture into services are into retail, petty trading and 
other informal activities. Osei and Jedwab (2016) suggest that these patterns of labor movement may be largely driven by productivity differentials between the major economic sectors. Thus, contrary to the traditional development trajectory, we observe a movement of labor from agriculture into services but not into manufacturing and this may be largely due to productivity differentials between the sectors. This means any development strategy anchored on industrialization serves as a clarion call for more attention to be paid to how to shore up productivity in the manufacturing sector. In this regard, it should be recognized that managerial capacity development is crucial for productivity growth as argued by several authors such a Bloom and Van Reenen (2007), Caselli and Gennaioli (2013) and Schmenner and Swink (1998).

In this study, we investigate the effect of training on Kaizen, offered to manufacturing enterprises in Ghana through a collaboration between the Japanese International Cooperation Agency (JICA) and Ghana's National Board for Small Scale Industries (NBSSI), on the firms' productivity and other performance indicators. Having been popularized by the success story of Toyota, a pioneer of Kaizen management technique, the impact of Kaizen on performance does not appear to be in dispute although the empirical evidences have largely emanated from Western countries (Humphrey 1995). A major source of contention is about the applicability of the technique to contexts other than Japan, especially in developing countries given that the Kaizen technique emanated from Japanese cultural philosophies. Kaplinsky (1995), however, argues that Kaizen may be suitable for the operating environment in developing countries due to its factor characteristics as well as the flexibility it provides in terms of descaling production and managing complexities associated with fluctuating macroeconomic conditions in developing countries.

This study contributes to the literature by providing an empirical analysis of the effect of Kaizen on the performance of enterprises in Ghana's stagnant manufacturing industry. We examine the impact of the training on Kaizen on firm productivity and other performance indicators such as profit and sales using propensity score matching (PSM) - a quasiexperimental technique. Our results show that the training has had significant effect on firm performance as well as a majority of indicators on behaviors and practices and/or process indicators. The rest of the study is organized as follows: Section 2 situates the study within the existing literature, while Sect. 3 provides a detailed outline of the methodology adopted in the study. Section 4 presents the results while conclusions are provided in Sect. 5. 


\section{Literature Review}

In an attempt to explain the huge cross-country differences in productivity, the literature has in recent times sought for answers at the micro level, as time-persistent differences in productivity among firms within narrowly defined industries have been reported (Foster et al. 2008). Microeconomic explanations for the differences in productivity across firms particularly in the same industry focus on the differences in factor inputs (i.e. labor and capital), technological varieties and intensities, and scale of economies (Schmenner and Swink 1998). However, recent studies reveal that high productivity is owed to not only factor intensities and/or technological advantage but also allocative efficiency (Hsieh and Klenow 2009; Restuccia and Rogerson 2008) and managerial capacity as well as skill content (Bloom and Van Reenen 2007; Caselli and Gennaioli 2013; Schmenner and Swink 1998). Kaplinsky (1995) argues that the social structure within which production occurs is also a crucial aspect of the production system, which may account for a non-negligible amount of the productivity differences across firms, industries and countries, emphasizing the importance of Kaizen or Japanese management techniques.

Kaizen involves three main principles (Berger 1997; Brunet and New 2003). The first which focuses on gradual improvements can lead to the creation of conducive atmosphere where any innovation would easily be accepted by workers and management (Brunet and New 2003), whereas the key objective of the second principle is about improving processes and reducing waste (Humphrey 1995). Contrary to the Taylor system of management in which less or no intellectual inputs are required from workers, third principle of Kaizen requires involving workers at all levels in decision making about processes that lead to gradual improvement (Styhre 2001). While the above principles are important, in practice, the nature and details of Kaizen may vary from one firm to the other or from one context to the other. Brunet and New (2003) report different and sometimes unique patterns of Kaizen implementation among a number of firms in Japan. For adoption outside of Japan, cultural barriers both from within the adopting firm and in the broader local context are important (Panizzolo et al. 2012; Recht and Wilderom 1998) so are constraints around quality of infrastructure and human capital development (Kaplinsky 1995). Within the firm, the commitment of the top management, effective communication among workers and the presence of a Kaizen Champion are also crucial (Recht and Wilderom 1998; Maarof and Mahmud 2016). 
Several authors have explored the processes by which Kaizen leads to productivity and performance improvement. For example, by invoking the theory of swift-even flow, ${ }^{1}$ Schmenner and Swink (1998) argue that Kaizen can increase the speed at which materials pass through a production process and this can lead to productivity improvement. Brown et al. (2015) argue that Kaizen enhances trust building between workers and management which has been found to have positive impact on labor productivity, financial performance as well as product quality.

Kaizen's attractiveness lies in the belief that it may have a positive impact on productivity. However, there are a few empirical studies examining the effect of Kaizen on productivity and firm performance particularly in developing countries. Moreover, a large proportion of available empirical work are case studies, focusing on a single or a couple of establishments. A case study of a public hospital in Sri Lanka shows that adopting total quality management (TQM) and $5 \mathrm{~S}$ (which stands for "sort," "set in order," "shine," "standardize," and "sustain") improved service quality by enhancing employee performance through good leadership and better team work (Withanachchi et al. 2007). Panizzolo et al. (2012) study four enterprises and find that Kaizen leads to a reduction in the amount of time needed to set up equipment for production to start. Similarly, Puvanasvaran et al. (2010) also find that Kaizen helps to reduce the time taken by a spare-part manufacturer in Malaysia to process sales order, with production lead falling by 15 percent. In another study on a university laboratory, Jiménez et al. (2015) report that preparation time for laboratory practicals reduces by 30 percent and risk of accidents also goes down after implementing $5 \mathrm{~S}$.

A few quantitative studies using experimental or quasi-experimental approaches to examine the impact of Kaizen in developing countries have started to emerge. Generally, these studies show that teaching Kaizen methods to enterprises (including micro- and small-scale ones) in developing countries shows a positive impact on productivity. For example, Higuchi et al. (2015) discuss a randomized controlled trial (RCT) of short-term management training on Kaizen for small manufacturers in two study sites in Vietnam and find that the training increases the value added of the participants who actually implemented the practices. Similarly, using an experimental approach to evaluate the effect of Kaizen on business performance of small enterprises in a metalworking cluster in Nairobi, Mano et al. (2014) report that enterprises that participated in Kaizen training have a significant increase in profits and value added but with no 
significant effect on sales revenue, compared to their counterparts that participated in other training programs. An earlier RCT study by Mano et al. (2012) to evaluate the effect of management training that involves some aspects of Kaizen for microenterprises was in Kumasi, also in Ghana. Significant positive impacts on performance are found. While Mano et al. (2012) focus mainly on microenterprises in a single cluster of fabricators, the current study provides more insights into the likely effect on Basic Kaizen on performance in that it covers firms from more manufacturing industries as well as small and medium enterprises.

\section{Methodology}

\subsection{The Intervention Under the Study}

Recognizing the critical need to develop management capabilities among small and medium-sized enterprises in Ghana, JICA in conjunction with Ghana's NBSSI has been implementing an intervention since 2012, which seeks to train small and medium enterprises (SMEs) in manufacturing to adopt Kaizen management techniques. Focusing mainly on four main administrative regions in Ghana (Ashanti, Northern, Brong Ahafo and Central regions), the participants received training on basic Kaizen principles and methods like 5S (sorting, setting, shining, standardizing and sustaining), waste reduction and visualization. Basic accounting principles like stock control, petty cash book keeping, recording of sales and accounts receivable and payables and other practices were included in the training.

The program started with a pilot, which was carried out in the Ashanti region between 2012 and 2014, after which a national project was designed to cover the other three regions but in a stepwise or cascaded fashion. The Ashanti and Northern regions' project started in 2015 and 2016 respectively, while that for firms in Brong Ahafo started in 2017 with firms in Central region expecting to receive the training in 2018. According to the implementers, the focus of the intervention on manufacturing enterprises was justified by the general belief that Kaizen management practices are most suitable for manufacturing firms. Hence, although the concept/practices could be applied in other business contexts, it was prudent to begin the introduction of the concept to the Ghanaian business environment by starting with manufacturing enterprises.

The training was administered to the enterprises through the NBSSI's Business Advisory Centers (BACs) in the targeted regions. The core 
mandate of BACs is that they provide business extension services in many areas including operational management practices. An essential feature of the training was that it involved Japanese experts on Kaizen (OJT) who initially delivered on-the-job-training (OJT) with NBSSI officials not only facilitating the training but also learning how to independently deliver training to their clients in the absence of Japanese experts. This was done to ensure continuity or sustainability of the program after the Japanese experts have left. In fact, between 2015 and 2017, self-implementation by the BACs has independently trained many enterprises with no direct involvement of the Japanese experts. Solely for the purpose of easily distinguishing between the firm trained by the Japanese experts and those trained by BACs, we refer to the former as OJT firms and the latter as self-implementation firms in the rest of this chapter.

\subsection{Data and Analytical Approach}

We set out to interview all the firms which had received the training. NBSSI/BAC officials provided us with a list of the enterprises that had received the training at the time of our survey, which took place between October and December 2017. They also provided us with a list of enterprises which had been selected for training but had not yet received the training or had just received training but yet to start actual implementation of the practices. We attempted to interview all these enterprises so they could serve as a control group for those that had received the training and started implementing the practices. We had to follow this approach because the intervention was not originally designed to allow for the use of rigorous impact assessment methods such as randomized control trials. In addition to a firm-level questionnaire which was administered to the manager of each of the firms, we also interviewed two employees (preferably a male and a female) from each firm that participated in the study. This allows us to assess the effect of the training on behavioral or process indicators from the perspectives of both the management and the employees in addition to examining the effect on firm-specific key performance indicators such as employment, output, value added, sales and profit.

Our interactions with NBSSI indicated that they approached enterprises which benefited from the training, although a few other enterprises did approach NBSSI on their own after learning about the benefits of the training from other beneficiaries. Once the enterprises meet assessment criteria, of which the details can be found in the assessment sheet provided 
in the Appendix to this chapter, they are admitted into the program. This means that generally the beneficiary enterprises did not only self-select into the program but their selection was also not based on any randomized process. Hence, in our attempt to assess the effect of the training on performance, we relied on propensity score matching (PSM) to examine the average treatment effect of the training by matching the treated enterprises (those which have received the training and implemented the practices) with those that have been qualified to participate in the training but are yet to receive the training and those that have just received the training but have not started implementing the practices. Using key time-invariant variables including educational background of the manager, subsector of manufacturing in which they operate, age of the manager, region and legal status of the enterprise, the treated firms were matched with the untreated ones using the nearest neighbor technique. The use of time-invariant variables was to help avoid endogeneity problems. The variables used in generating propensity scores for analyses at both management and employee levels are included in Table 12.1.

In addition to the PSM, we also used a random effect model to explore the effect of the training on the performance indicators, of which the details are presented in the Appendix. Due to some disadvantages associated the PSM methods, such as the reliance on conditional independence assumption (Bryson et al. 2002) and biasedness associated with researcher's control over selected observables for matching (King and Nielson 2018), the random effect model was used to complement the PSM results as well as serve a robustness check. Also presented in the Appendix, the results of random effect model are qualitatively similar to the PSM results.

A total of 184 enterprises were interviewed from the three administrative regions-Ashanti, Northern and Brong Ahafo regions-where Kaizen had been introduced. ${ }^{2}$ Of the total interviewed, the treatment group constituted 98 firms while the remainder were in the control group. There were 110 enterprises in the Ashanti region (64 for treatment and 46 for control), 45 in the Northern region ( 22 for treatment and 23 for control) and 29 in the Brong Ahafo. All the enterprises in Brong Ahafo were in the control group and this was because 14 of these enterprises which had just received the training at the time of the survey were yet to start implementation of the practices while the remaining 15 had only been selected to receive the training. 
Table 12.1 Description of variables and how they were generated for analysis

\begin{tabular}{|c|c|}
\hline Variable & Description of variables \\
\hline Wmale & Male worker $=1$, female as base \\
\hline w_age & Age of worker in years \\
\hline Juniorstaff & Worker is a junior staff $=1$, zero otherwise \\
\hline Farmworker & Worker is related to manager $=1$, zero otherwise \\
\hline Wedusss & Worker has completed senior secondary education (SSS) \\
\hline Weduhigher & Worker's education is higher than SSS $=1$, zero otherwise \\
\hline Wedubasic & Worker's education is basic $=1$, zero otherwise \\
\hline Male & Gender of the manager-male manager, female as base \\
\hline Age & Age of the manager in years \\
\hline proficient_eng & Manager is proficient in English $=1$, zero otherwise \\
\hline ashantiBA & Firm in Ashanti or Brong Ahafo regions of Ghana \\
\hline Registered & Registered firm $=1$, zero otherwise \\
\hline sole_pro & Sole proprietor $=1$, zero otherwise \\
\hline Foodind & Food or water industry $=1$, others zero \\
\hline Wearingapparel & Wearing apparel industry $=1$, others zero \\
\hline Metalwork & $\begin{array}{l}\text { Fabrication of metals, machine installation industry }=1 \text {, zero } \\
\text { otherwise }\end{array}$ \\
\hline Riskaverse & $\begin{array}{l}\text { Manager is risk averse }=1 \text {, zero otherwise. Choose between the } \\
\text { following two options: Receive GHष } 100 \text { for sure (option } 1 \text { ) or flip } \\
\text { a coin and receive } 0 \text { if it's tail or GH\& } 300 \text { if it's head (option 2) }\end{array}$ \\
\hline Preferstoday & $\begin{array}{l}\text { Manager is present biased }=1 \text {, zero otherwise. Choose between the } \\
\text { following options: Receive GH } 1000 \text { today (option } 1 \text { ) or receive } \\
\text { GHC } 1500 \text { for sure one year from now (option } 2 \text { ) }\end{array}$ \\
\hline Wriskaverse & $\begin{array}{l}\text { Worker is risk averse }=1 \text {, zero otherwise. Choose between the } \\
\text { following options: Receive GHष } 100 \text { for sure (option 1) or flip a } \\
\text { coin and receive } 0 \text { if it's tail or GHष } 300 \text { if it's head (option 2) }\end{array}$ \\
\hline Wpreferstoday & $\begin{array}{l}\text { Worker is present biased = } 1 \text {, zero otherwise. Choose between the } \\
\text { following options: Receive GH } 1000 \text { today (option } 1 \text { ) or receive } \\
\text { GHథ } 1500 \text { for sure one year from now (option 2) }\end{array}$ \\
\hline Loutput & Log of the value of annual output \\
\hline Loutputpworker & Log of annual output per worker \\
\hline Lsales & Log of the value of annual sales \\
\hline Lvalueaddpworker & Log of annual value added per worker \\
\hline Lprofit & Log of annual profit \\
\hline
\end{tabular}

\section{Analysis and Results}

Table 12.1 provides a list of variables used in the analysis and how they were constructed. The variables used in the probit regression models which generated the propensity scores for matching the treated firms with the control firms are also included in Table 12.1. Our matching produced 
a strong common support between the treated and control firms with a region of common support of $[0.03,0.91]$ and only one treatment firm being off the common support region and not included in the analysis. We included the age of the manager in the probit regression instead of the age of the firm because our preliminary analysis revealed that the age of the manager was significantly correlated with the age of the firm. Meanwhile, a high number of the enterprises in the study are sole proprietorships whose owners' general experiences particularly from previous employment may be more relevant in this context than the age of their current firm.

Table 12.2 compares the treatment and control groups based on the characteristics of the firms and/or managers. The table shows that, in terms of the age of managers, there is no significant difference between treatment and control groups. Similarly, there is no significant difference between the two groups with respect to the gender of the manager, although the majority of the managers in both groups are males (above 70 percent). In the treatment group, 43 percent of the managers have higher than secondary education, but 29.6 percent of the control managers have attained this level of education. ${ }^{3}$ A higher percentage of managers of the control firms (58.2 percent) have secondary education, compared to 29.1 percent for the treatment group. On the other hand, a higher percentage of the treatment group managers have basic education (27.9 percent) as

Table 12.2 Firm/manager's characteristics by whether firm is treated

\begin{tabular}{lrrrr}
\hline Variables & Control & Treatment & $\begin{array}{l}\text { Chi } / \mathrm{T}- \\
\text { test }\end{array}$ & P-values \\
& & & -0.745 & 0.457 \\
\hline Mean age of managers & 43.4 & 44.6 & 0.368 & 0.544 \\
Proportion of male managers & 70.4 & 74.4 & 10.070 & 0.002 \\
English proficiency of managers & 33.7 & 57.0 & 7.140 & 0.008 \\
Manager has basic education & 12.2 & 27.9 & 15.694 & 0.000 \\
Manager has sec. education & 58.2 & 29.1 & 3.592 & 0.058 \\
Manager has above sec. education & 29.6 & 43.0 & 14.180 & 0.000 \\
Proportion of firms registered & 71.4 & 93.0 & 0.968 & 0.026 \\
Proportion of firms with a sole proprietor & 82.7 & 68.6 & 9.025 & 0.843 \\
Proportion of firms in food/water industry & 39.8 & 38.4 & & 0.003 \\
Proportion of firms in wearing apparel & 26.5 & 9.3 & 1.099 & 0.295 \\
industry & & & 0.568 & 0.451 \\
Proportion of firms in metalwork industry & 7.1 & 11.6 & 0.644 & 0.422 \\
Proportion of risk averse managers & 71.4 & 66.3 & & \\
Proportion of present bias managers & 83.7 & 79.1 & & \\
\hline
\end{tabular}


compared to managers with basic education in the control group (12.2 percent). Registered firms constitute 93 percent of the treatment group which is statistically different from the proportion of the firms in the control group that have been registered (71.4 percent). This follows from the fact that a higher proportion of the control firms are sole proprietorships (82.7 percent) as compared to the treatment firms (69 percent).

In terms of the distribution by industry type, we observe a slight difference in the proportion of the firms for treatment and control groups in the food/water industries (38.4 percent for treatment and 39.8 percent for control), but relatively more control firms are in wearing and apparel (26.5 percent) than treatment $(9.3$ percent $)$. Responses from a single hypothetical question to measure risk aversion show that there is no significant difference between the treatment managers and the control managers in terms of their tendency to take risk. About 71.4 percent of the control managers are risk averse as compared to 66.3 percent of the treatment managers. Similarly, about 83.7 percent of the control managers and 79 percent of the treatment managers prefer to receive a Ghana Cedis (GHC) 1000 today instead of GHC 1500 a year later. This implies that managers of both groups on average are highly present-bias and are impatient for returns on investment.

The mean of selected outcomes (number of workers, annual output per worker, sales, value added per worker and profit) by treatment status, gender of the manager, region of Ghana and other variables is presented in Table 12.3. These measures show the relative size of the firms. The firms trained by the Japanese experts (OJT firms) are larger than those trained by the BACs of NBSSI (self-implementation firms), which in turn are larger than the control. With the exception of value added per worker, the average values of workers, output per worker, sales and profit are higher for the treatment firms than for the control firms. Firms in the Ashanti/Brong Ahafo region of Ghana are larger than those in the Northern region. Registered firms perform better than unregistered ones, but sole proprietors do not have better measures of performance than other types of firm.

The average values of the measures of performance in Table 12.3 increase with the education of the manager of the firm. The values for firms with managers with higher than secondary education are higher than average values for firms with managers having secondary education, which are in turn higher than those with basic education. Even though the average number of workers of firms with female managers is 22 and that of male managers is 21 , output per worker, sales, value added per worker and 
Table 12.3 Mean of selected outcomes

\begin{tabular}{|c|c|c|c|c|c|c|}
\hline & Characteristics & Workers & $\begin{array}{l}\text { Output } \\
\text { per worker }\end{array}$ & Sales & $\begin{array}{l}\text { Value added } \\
\text { per worker }\end{array}$ & Profit \\
\hline \multirow{4}{*}{$\begin{array}{l}\text { Type of } \\
\text { treatment }\end{array}$} & OJT & 31 & 28.95 & 1061.39 & 12.29 & 397.96 \\
\hline & $\begin{array}{l}\text { Self- } \\
\text { implementation }\end{array}$ & 29 & 17.95 & 382.17 & 8.98 & 247.33 \\
\hline & Treatment & 31 & 25.05 & 804.93 & 11.12 & 346.54 \\
\hline & Control & 14 & 20.44 & 323.09 & 14.32 & 203.73 \\
\hline \multirow[t]{2}{*}{ Regions } & Northern region & 16 & 12.13 & 145.76 & 4.77 & 55.59 \\
\hline & $\begin{array}{l}\text { Ashanti/BA } \\
\text { region }\end{array}$ & 23 & 25.39 & 662.54 & 15.07 & 338.42 \\
\hline \multirow[t]{3}{*}{ Education } & $\begin{array}{l}\text { Manager has basic } \\
\text { edu. }\end{array}$ & 16 & 15.85 & 148.08 & 11.62 & 63.20 \\
\hline & $\begin{array}{l}\text { Manager has sec. } \\
\text { edu. }\end{array}$ & 16 & 22.42 & 362.43 & 12.42 & 161.11 \\
\hline & $\begin{array}{l}\text { Manager has } \\
\text { higher edu. }\end{array}$ & 31 & 26.04 & 950.73 & 14.08 & 500.35 \\
\hline \multirow{4}{*}{$\begin{array}{l}\text { Registration } \\
\text { status } \\
\text { Ownership }\end{array}$} & Not registered & 12 & 13.93 & 117.08 & 10.05 & 81.93 \\
\hline & Registered & 24 & 24.53 & 635.97 & 13.55 & 311.92 \\
\hline & $\begin{array}{l}\text { Non-sole } \\
\text { proprietor }\end{array}$ & 40 & 37.29 & 1059.26 & 20.35 & 449.97 \\
\hline & Sole proprietor & 16 & 18.06 & 382.47 & 10.63 & 221.16 \\
\hline \multirow[t]{7}{*}{ Industry } & Industry: Food & 24 & 28.82 & 528.62 & 18.05 & 238.20 \\
\hline & Wearing apparel & 15 & 4.41 & 155.24 & 1.50 & 107.93 \\
\hline & Wood products & 20 & 30.19 & 522.68 & 24.27 & 326.50 \\
\hline & Metals/machines & 25 & 33.68 & 1448.58 & 12.76 & 632.43 \\
\hline & Chemicals & 39 & 9.43 & 827.79 & 4.07 & 553.81 \\
\hline & $\begin{array}{l}\text { Paper, plastics, } \\
\text { textiles }\end{array}$ & 10 & 20.48 & 528.28 & 1.91 & 89.42 \\
\hline & Others & 14 & 10.50 & 262.94 & 1.89 & 73.48 \\
\hline \multirow[t]{2}{*}{ Gender } & Male manager & 21 & 25.80 & 672.53 & 15.52 & 334.44 \\
\hline & Female manager & 22 & 12.74 & 185.92 & 5.27 & 84.39 \\
\hline Total & Total & 21 & 22.54 & 536.67 & 12.89 & 269.95 \\
\hline
\end{tabular}

Note: Except for the number of workers, all the variables are measured in thousands Ghana cedis

profit for firms with male managers are higher than those of female managers. In terms of the number of workers, sales and profit, firms involved with machines and metal work and those in chemicals are larger than the other industry types.

The gender distribution of the employees who were interviewed shows that there are more males (71.7 percent in treatment and 58.6 percent in control) in our sample than females. By the research design, we expected 
an equal distribution between males and females among the employees. However, the higher proportion of males may be due to the fact that a lot of manufacturing activities in Ghana are male dominated. Both treatment and control groups have similar proportion of junior workers (about 36.4 percent each group). There is no statistically significant difference between the treatment and control with regard to the proportion of workers who are related to the owner or manager of the enterprises. The difference in the proportions for basic and secondary education between two groups is not significant. On the contrary, a higher proportion of workers have more than senior secondary education in the treatment group (14.5 percent) as compared to the control group ( 5.4 percent).

The results from the PSM analysis of the effect of training on key indicators of behaviors and management practices are presented in Table 12.4 from the perspective of the managers. The nearest neighbor matching technique is used, with two nearest neighbors giving the smallest bias of 11 .1. It

Table 12.4 Average treatment effect on key practices using PSM—management

\begin{tabular}{|c|c|c|c|c|c|}
\hline Management practice & Treated & Control & Difference & $\begin{array}{l}\text { Std. } \\
\text { error }\end{array}$ & T-stat. \\
\hline Good workers' attitude & 0.624 & 0.235 & 0.388 & 0.086 & 4.5 \\
\hline Profited from suggestions & 0.624 & 0.569 & 0.055 & 0.094 & 0.59 \\
\hline Cleaning & 0.800 & 0.400 & 0.400 & 0.087 & 4.61 \\
\hline Placing tools & 0.729 & 0.298 & 0.431 & 0.080 & 5.37 \\
\hline Kaizen committee & 0.424 & 0.161 & 0.263 & 0.073 & 3.59 \\
\hline Floor plan & 0.565 & 0.149 & 0.416 & 0.071 & 5.82 \\
\hline Defect reduction & 0.706 & 0.361 & 0.345 & 0.089 & 3.89 \\
\hline Workers' attendance record & 0.682 & 0.380 & 0.302 & 0.089 & 3.38 \\
\hline Sales record & 0.647 & 0.490 & 0.157 & 0.094 & 1.66 \\
\hline Products record & 0.859 & 0.486 & 0.373 & 0.087 & 4.26 \\
\hline $\begin{array}{l}\text { Keeping accounts receivable/payable } \\
\text { records }\end{array}$ & 0.824 & 0.502 & 0.322 & 0.088 & 3.64 \\
\hline Keeping a petty cash record? & 0.765 & 0.518 & 0.247 & 0.091 & 2.72 \\
\hline Risk averse & 0.659 & 0.714 & -0.055 & 0.087 & -0.630 \\
\hline Prefers today & 0.788 & 0.800 & -0.012 & 0.075 & -0.160 \\
\hline $\begin{array}{l}\text { Most people in this company can be } \\
\text { trusted (agree/strongly agree) }\end{array}$ & 0.671 & 0.690 & -0.020 & 0.090 & -0.22 \\
\hline $\begin{array}{l}\text { Most of my customers can be trusted } \\
\text { (agree/strongly agree) }\end{array}$ & 0.647 & 0.624 & 0.024 & 0.092 & 0.25 \\
\hline $\begin{array}{l}\text { Most of my suppliers can be trusted } \\
\text { (agree/strongly agree) }\end{array}$ & 0.624 & 0.592 & 0.031 & 0.093 & 0.34 \\
\hline
\end{tabular}


can be stated that most of the improved practices by the treatment firms as compared to the control can be attributed to the training on Kaizen. By and large, the results strongly indicate that behaviors and practices in the treatment group appear better than the situation in the control group. The differences between the two groups on the majority of the variables are not only statistically significant but are also in favor of the treatment group.

The proportion of managers reporting good workers' attitude toward work is higher in the treatment group than in the control group. A similar statement can be made about daily cleaning at the close of work, placing tools in the right place, having a Kaizen committee and having a floor plan/marking. The proportions of managers in the treatment group who reported that they have got measures to reduce defects as well as recording worker's attendance are significantly higher for the treatment group. The results also show that the training significantly improved the record keeping by the firms in terms of petty cash records and account receivables record. The matched difference in the proportion of firms keeping sales records is not significant, even though the unmatched is significant. This should not be surprising because most firms already keep sales records and thus only a few may have to start the practice if they were not records.

The results however show no effect of the training on risk and time preference of the managers, trust among workers and trust in customers and suppliers. We find this unsurprising as trust appears to be more embedded in a broader social system, whereas risk and time preferences are generally intransigent especially in the short term. The results from the employees' perspective largely align with those of the managers. Additionally, we find statistically significant differences in favor of the treatment group for questions or indicators that only pertains to the employees such as the perception of workers in their suggestions to management, knowledge of the firm's sales target or policies, knowledge of the mission of the firm and labeling of stock items.

In addition to the impact of the training on behavioral or process indicators discussed above, we also analyze the likely impact of the training on performance indicators using PSM and the results are presented in Table 12.5. Here, we performed the analysis using the averages of the firm's performance indicators for the period 2012-2017 or the log of the averages for the period. It is during this period that the firms were treated. In all of the performance measures, the difference between the treatment and control is statistically significant in the unmatched samples. After matching, the results from PSM show that the training has had statistically 
Table 12.5 Average treatment effects after matching at the firm level

\begin{tabular}{llrrrrl}
\hline Variable & Sample & Treated & Controls & Difference & S.E. & T-stat \\
\hline Mean number of workers & Unmatched & 28.79 & 14.57 & 14.23 & 3.78 & 3.76 \\
& ATT & 29.11 & 13.09 & 16.02 & 3.99 & 4.01 \\
Mean $\log$ of output & Unmatched & 12.12 & 11.01 & 1.11 & 0.26 & 4.22 \\
& ATT & 12.15 & 11.43 & 0.71 & 0.33 & 2.13 \\
Mean log of output per & Unmatched & 9.18 & 8.67 & 0.51 & 0.21 & 2.46 \\
worker & ATT & 9.19 & 9.05 & 0.14 & 0.27 & 0.53 \\
Mean $\log$ of sales & Unmatched & 12.41 & 11.32 & 1.09 & 0.26 & 4.26 \\
Mean log of value added & ATT & 12.43 & 11.64 & 0.79 & 0.32 & 2.47 \\
per worker & Unmatched & 8.37 & 7.68 & 0.69 & 0.25 & 2.73 \\
Mean $\log$ of profit & ATT & 8.39 & 8.13 & 0.26 & 0.34 & 0.76 \\
& Unmatched & 11.35 & 9.98 & 1.37 & 0.3 & 4.62 \\
& ATT & 11.35 & 10.04 & 1.31 & 0.39 & 3.4 \\
\hline
\end{tabular}

significant effects on the average number of workers, output, sales and profit, whereas the effect on value added per worker and output per worker is unexpectedly insignificant. This suggests an appreciable impact of the training on Kaizen. But again, since the firms were not randomly assigned into treatment and control before the training, a strict causal relationship is limited here.

\section{Conclusion}

Industrialization efforts by African countries, and in particular Ghana, have not yielded substantial dividends. Ghana's manufacturing value added has seen no long-term growth since political independence and has disappointingly declined in recent years while informal services sector activities have blossomed, accounting for large proportion of employment. The key question is about how to place Ghana's manufacturing sector as well as those of many SSA countries with a struggling manufacturing sector on a path of a stable and sustainable growth. Policies, programs and/or interventions that would bring about productivity growth in the manufacturing sector are likely to contribute significantly to a vitalization of SSA's struggling manufacturing sectors. In line with this call, JICA together with NBSSI has introduced Kaizen management techniques through training to manufacturing enterprises in Ghana, and this study sought to establish whether the intervention has had any major impact on the performance of the manufacturing firms in Ghana. 
Similar to findings from empirical studies such as Higuchi et al. (2015) and Mano et al. (2014), our results show that the adoption of Kaizen has had significant impact on the performance of manufacturing enterprises that participated in the training and have consequently implemented the methods, practices and techniques associated with Kaizen. Specifically, we found evidence of a significant impact of the training on the firms' number of workers, sales, profit and output. This seems to provide some support for the argument by Kaplinsky (1995) and Schmenner and Swink (1998) that Kaizen, which emanated from Japanese cultural philosophy, may be applicable in context other than Japan including developing countries such as Ghana.

This study represents a contribution to the literature on the likely effect of Kaizen on the productivity and performance in developing countries, particularly in Africa. In terms of policy, the findings of the study suggest that extensive promotion of Kaizen as a management technique among a broad spectrum of manufacturing enterprises, and perhaps businesses in other economic sectors, could contribute significantly to rejuvenating manufacturing in Ghana and in SSA. We suggest that factoring Kaizen into Ghana's recent policy to establish a factory in each administrative district may enhance the likelihood that the policy will succeed.

\section{ApPENDIX}

Though the survey was conducted in a one-time period, we collected information on the performance and input variables from 2011 (i.e. a year before the program started) to 2017, which allows us to model the effect of training on performance using a panel framework. We consider the following regression model:

$$
y_{i t}=\alpha_{i}+\beta_{1} \text { trt }_{i t}+\beta_{2} \text { treat }_{i}+\sum_{i}^{t} \beta_{3 i} \text { year }_{t}+\sum_{i}^{k} \beta_{4 i} x_{i t}+\varepsilon_{i t}
$$

where $y$ represents the performance variable; treat equals 1 if the firm is in the treatment group, otherwise zero; year are time dummies from 2011 to 2017; and $x$ are control variables. trt is derived from an interaction between the treat dummy and the year dummies, taking a value of zero for 
all the years before training but one for all the years from the year of training onward. $\alpha_{i}$ are the random individual-specific effects, $\beta_{i}$ are the coefficients and $\varepsilon_{i t}$ is an idiosyncratic error. In this model, $\beta_{1}$, the coefficient of $t r t$, measures the impact of the training on the performance variables.

We estimated the parameters of the regression equation above using random effects. Our choice of random effect over fixed effects was informed by the fact that most of our regressors in the equation are time invariant, for which fixed effects models do not provide coefficients on. Moreover, the Breusch and Pagan Lagrange Multiplier Test which compares random effects model with pooled ordinary least squares (OLS) regression showed that for all the performance variables considered, the random effect models were better than pooled OLS regression. However, the downside of the panel model is that it does not allow us to adequately address selection problems. Another problem is that the results may be affected by respondents' recall bias because the respondents had to provide information on activities that had taken place a couple of years or several years ago in some cases. Measured by the coefficient of trt, the regression results show that with the exception of output and value added per worker, the intervention had a positive and significant effect on four out of six performance indicators considered in this study. Qualitatively, these results generally support the PSM results about the positive impact of the intervention on the firms' performance (Tables 12.6 and 12.7). 


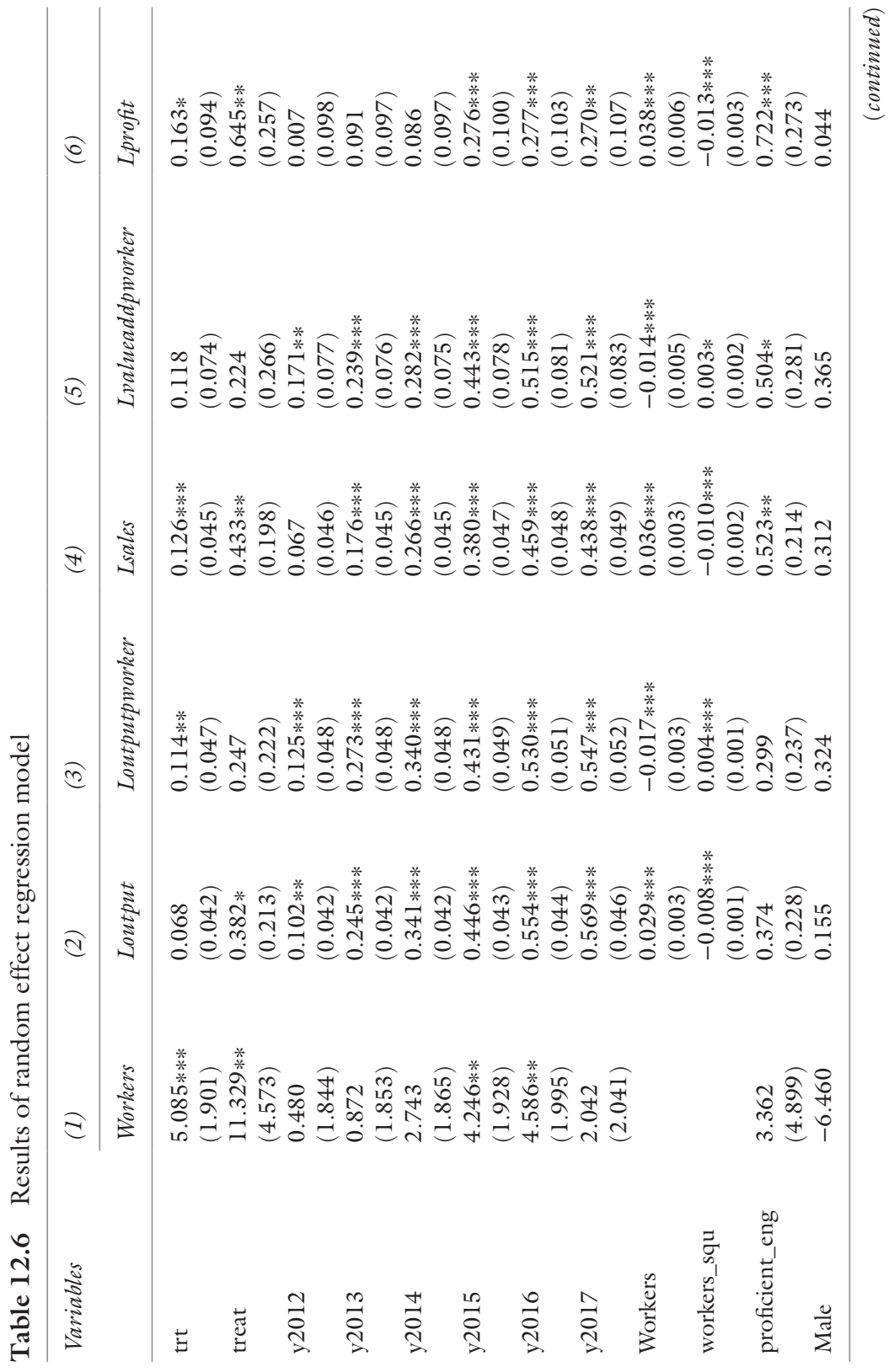




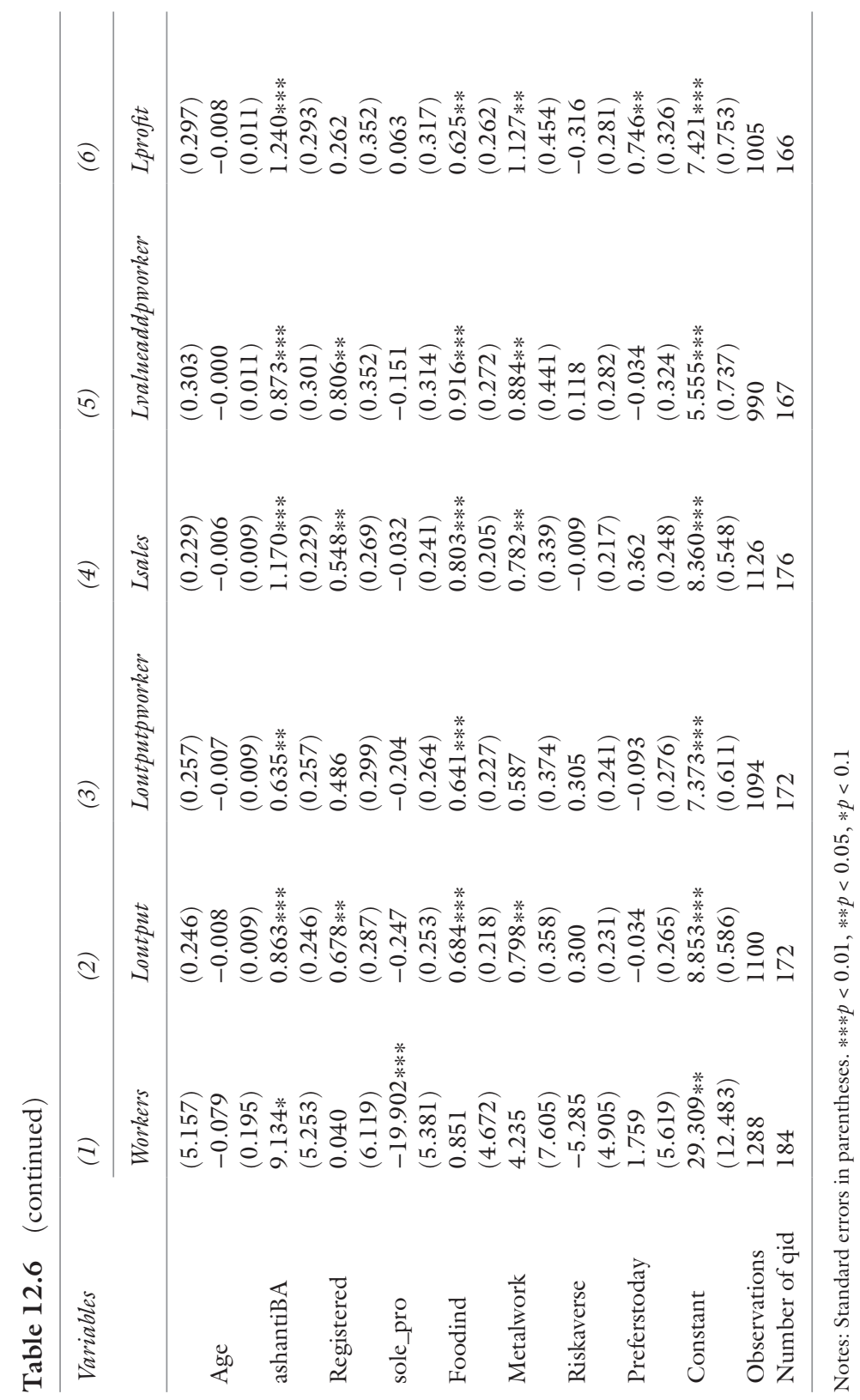


Table 12.7 Enterprise selection assessment sheet

\begin{tabular}{|c|c|c|c|c|}
\hline Overall Score & \multicolumn{4}{|c|}{ Score } \\
\hline $\begin{array}{l}\text { 1. Company assessment (Point 1: Not, 2: Fair 3: Good) } \\
\text { (1) Active client of BAC }\end{array}$ & 1 & L & 2 & 3 \\
\hline (2) Registration with Register General Department & & 1 & 2 & 3 \\
\hline $\begin{array}{l}\text { (3) Number of employees (both fully employed and part-time) } \\
\text { (Score: 1. 1-3, 2. 4-6, 3. 7-10, 4. 11-15, 5: 16+) }\end{array}$ & \multicolumn{4}{|c|}{12345} \\
\hline (4) Gender balance of the organization & & & 2 & 3 \\
\hline (5) Willingness to implement KAIZEN & & 1 & 3 & 6 \\
\hline (6) Growth stage of the Organization based on NBSSI ranking system & & & 2 & 3 \\
\hline (7) Book and record keeping & & 1 & 2 & 3 \\
\hline (8) English literacy rate of management & & 1 & 2 & 3 \\
\hline (9) Willingness to disclose or share business information & & 1 & 2 & 3 \\
\hline (10) Activeness & & 1 & 2 & 3 \\
\hline \multicolumn{5}{|l|}{ Sub total } \\
\hline 2. Applicable Basic KAIZEN Menu (Point 1: Not sure 2: Applicable) & \multicolumn{4}{|c|}{1} \\
\hline (1) 5 S including Seiton board & \multicolumn{4}{|c|}{1} \\
\hline (2) 7Wastes & \multicolumn{4}{|c|}{1} \\
\hline (3) Factory layout change (Minor) & \multicolumn{4}{|c|}{1} \\
\hline (4) Reduction of defects & \multicolumn{4}{|c|}{1} \\
\hline (5) Inventory Control & \multicolumn{4}{|c|}{1} \\
\hline (6) Code of Conduct & \multicolumn{4}{|c|}{1} \\
\hline (7) Organization chart & \multicolumn{4}{|c|}{1} \\
\hline (8) Line balancing (Minor) & \multicolumn{4}{|c|}{1} \\
\hline (9) Skill map & \multicolumn{4}{|c|}{1} \\
\hline (10) Work standard & \multicolumn{4}{|c|}{1} \\
\hline \multicolumn{5}{|l|}{ Sub total } \\
\hline 3. Expectation of KAIZEN achievement (Point 1: Not sure 2: Achievable) & \multirow{2}{*}{\multicolumn{4}{|c|}{$\begin{array}{l}1 \\
1\end{array}$}} \\
\hline (1) 5 S including Seiton board & & & & \\
\hline (2) 7Wastes (shortening of transport) & \multicolumn{4}{|c|}{12} \\
\hline (3) Factory layout change (Minor), shortening of transport & \multicolumn{4}{|c|}{1} \\
\hline (4) Reduction of defects & \multicolumn{4}{|c|}{1} \\
\hline (5) Inventory Control & \multicolumn{4}{|c|}{1} \\
\hline (6) Code of Conduct (Absenteeism) & \multicolumn{4}{|c|}{1} \\
\hline (7) Organization chart & \multicolumn{4}{|c|}{1} \\
\hline (8) Line balancing (Minor) & \multicolumn{4}{|c|}{1} \\
\hline (9) Skill map (Multi-skilled worker) & \multicolumn{4}{|c|}{1} \\
\hline (10) Work standard & & 1 & & 2 \\
\hline Sub total & & & & \\
\hline $\begin{array}{l}\text { 4. Recommendation products by GoG } \\
\text { (Point 0: Not recommended } \quad \text { 10: Recommended) }\end{array}$ & & 0 & & 5 \\
\hline $\begin{array}{l}\text { 5. Local industry development (Applicability to many other enterprises } \\
\text { in the same industry.) } \\
\text { (Point 3: Somehow, 5: Fair, 8: Above average 10: Fully) }\end{array}$ & 3 & 5 & 8 & 10 \\
\hline
\end{tabular}


Table 12.7 (continued)

\begin{tabular}{|c|c|c|}
\hline $\begin{array}{l}\text { 6. Access to the company } \\
\text { (Point 1: within } 30 \text { minutes from BAC) } \\
\text { (Point 3: between } 30 \text { and } 60 \text { minutes from BAC) } \\
\text { (Point 5: } 60 \text { minutes+ from BAC) }\end{array}$ & 13 & 5 \\
\hline $\begin{array}{l}\text { 7. Export potential or import substitute } \\
\text { (Point 0: No potential } \quad \text { Point 5: Potential) }\end{array}$ & 0 & 5 \\
\hline G. Total (100 points) & & \\
\hline
\end{tabular}

Source: Project implementers-National Board for Small Scale Industries (NBSSI) and JICA Ghana office

\section{Notes}

1. This theory holds that the swifter and more even material flow through a process, the more productive that process is (Schmenner and Swink 1998, $102)$.

2. Central region was not included in the survey because no enterprise in this region had received the training.

3. The differences in educational attainment may have implications for the results particularly with regard to understanding and assimilating Kaizen concepts during the training. Hence, in both PSM (and regression analysis presented in the Appendix), we use the English proficiency of the manager as a matching variable in the case of PSM and a control variable in the case of the regression analysis.

\section{REFERENCES}

Bell, M., and K. Pavitt. 1997. Technological Accumulation and Industrial Growth: Contrasts Between Developed and Developing Countries. In Technology, Globalization and Economic Performance, ed. Daniele Archibugi and Jonathan Michie, 83-137. Cambridge: Cambridge University Press.

Berger, A. 1997. Continuous Improvement and Kaizen: Standardization and Organizational Designs. Integrated Manufacturing Systems 8 (2): 110-117.

Bloom, N., and J. Van Reenen. 2007. Measuring and Explaining Management Practices Across Firms and Countries. The Quarterly Journal of Economics 122 (4, Nov.): 1351-1408.

Brown, S., D. Gray, J. McHardy, and K. Taylor. 2015. Employee Trust and Workplace Performance. Journal of Economic Behavior \& Organization 116 (Aug.): 361-378.

Bruhn, M., and B. Zia. 2013. Stimulating Managerial Capital in Emerging Markets: The Impact of Business Training for Young Entrepreneurs. Journal of Development Effectiveness 5 (2): 232-266. 
Brunet, A.P., and S. New. 2003. Kaizen in Japan: An Empirical Study. International Journal of Operations \& Production Management 23 (12): 1426-1446.

Bryson, A., Dorsett, R., and Purdon, S. 2002. The Use of Propensity Score Matching in the Evaluation of Labour Market Policies. Working Paper No. 4. Department for Work and Pensions.

Caselli, F., and Gennaioli, N. 2013. Dynastic Management. Economic Inquiry 51 (1): 971-996.

Diop, M. 2017. World Bank's Vice President for Africa Institute of South-South Cooperation and Development (ISSCAD), Peking University, China: Beijing. Speech Delivered on 30 November 2017.

Egbetokun, A., R. Atta-Ankomah, O. Jegede, and E. Lorenz. 2016. Firm-level Innovation in Africa: Overcoming Limits and Constraints. Innovation and Development 6 (2): 161-174.

Foster, L., J. Haltiwanger, and C. Syverson. 2008. Reallocation, Firm Turnover, and Efficiency: Selection on Productivity or Profitability? American Economic Review 98 (1): 394-425.

$\mathrm{Fu}, \mathrm{X} .2015$. China's Path to Innovation. Cambridge: Cambridge University Press.

Ghana Statistical Service. 2013. 2010 Population \& Housing Census National Analytical Report. May. Accra, Ghana: Author.

- 2015. Annual Gross Domestic Product-September 2015 Edition. Accra, Ghana: Author.

Higuchi, Y., V.H. Nam, and T. Sonobe. 2015. Sustained Impacts of Kaizen Training. Journal of Economic Behaviour \& Organization 120 (Dec.): 189-206.

Hsieh, C.T., and P.J. Klenow. 2009. Misallocation and Manufacturing TFP in China and India. Quarterly Journal of Economics 124 (4): 1403-1448.

Humphrey, J. 1995. Industrial Reorganization in Developing Countries: From Models to Trajectories. World Development 23 (1): 149-162.

Jiménez, M., L. Romero, M. Domínguez, and M. del Mar Espinosa. 2015. 5S Methodology Implementation in the Laboratories of an Industrial Engineering University School. Safety Science 78 (Oct.): 163-172.

Kaplinsky, R. 1995. Technique and System: The Spread of Japanese Management Techniques to Developing Countries. World Development 23 (1): 57-71.

Kim, Y. 2014. China-Africa Technology Transfer: A Matter of Technology Readiness. CCS Commentary. Stellenbosch: Centre for Chinese Studies. Accessed March 24, 2016. http://www.ccs.org.za/wp-content/uploads/ 2014/02/CCS_Commentary_China_Africa_Tech_2014_YKl.pdf.

King, G., and R. Nielson. 2018. Why Propensity Score Matching Should Not Be Used for Matching? December. Accessed February 10, 2018. https://gking. harvard.edu/files/gking/files/psnot.pdf.

Maarof, M.G., and F. Mahmud. 2016. A Review of Contributing Factors and Challenges in Implementing Kaizen in Small and Medium Enterprises. Procedia Economics and Finance 35: 522-531. 
Mano, Y., J. Akoten, Y. Yoshino, and T. Sonobe. 2014. Teaching KAIZEN to Small Business Owners: An Experiment in a Metalworking Cluster in Nairobi. Journal of the Japanese and International Economies 33 (Sep.): 25-42.

Mano, Y., A. Iddrisu, Y. Yoshino, and T. Sonobe. 2012. How Can Micro and Small Enterprises in Sub-Saharan Africa Become More Productive? The Impacts of Experimental Basic Managerial Training. World Development40 (3): 458-468.

Osei, R.D., and R. Jedwab. 2016. Structural Change in a Poor Country: New Historical Evidence from Ghana. In Structural Change, Fundamentals and Growth, ed. Margaret McMillan, Dani Rodrick, and Claudia Sepulveda, 161196. Washington, DC: International Food Policy Research Institute.

Panizzolo, R., P. Garengo, M.K. Sharma, and A. Gore. 2012. Lean Manufacturing in Developing Countries: Evidence from Indian SMEs. Production Planning o Control 23 (10-11): 769-788.

Puvanasvaran, A.P., S.T. Kerk, and A.R. Ismail. 2010. A Case Study of Kaizen Implementation in SMI. National Conference in Mechanical Engineering Research and Postgraduate Studies (2nd NCMER 2010) 3-4 December 2010. Faculty of Mechanical Engineering. UMP Pekan, Kuantan, Pahang, Malaysia: 374-392.

Recht, R., and C. Wilderom. 1998. Kaizen and Culture: On the Transferability of Japanese Suggestion Systems. International Business Review 7 (1): 7-22.

Restuccia, D., and R. Rogerson. 2008. Policy Distortions and Aggregate Productivity with Heterogeneous Establishments. Review of Economic Dynamics 11 (4): 707-720.

Rodrik, D. 2015. Premature Deindustrialization. Working Paper No. 20935. Cambridge, MA: National Bureau of Economic Research. http://papers.nber. org/tmp/65392-w20935.pdf.

Schmenner, R.W., and M.L. Swink. 1998. On Theory in Operations Management. Journal of Operations Management 17 (1): 97-113.

Styhre, A. 2001. Kaizen, Ethics, and Care of the Operations: Management After Empowerment. Journal of Management Studies 38 (6): 795-810.

Withanachchi, N., Y. Handa, K.K.W. Karandagoda, P.P. Pathirage, N.C.K. Tennakoon, and D.S.P. Pullaperuma. 2007. TQM Emphasizing 5-S Principles: A Breakthrough for Chronic Managerial Constraints at Public Hospitals in Developing Countries. International Journal of Public Sector Management 20 (3): 168-177. 
Open Access This chapter is licensed under the terms of the Creative Commons Attribution 4.0 International License (http://creativecommons.org/licenses/ by $/ 4.0 /$ ), which permits use, sharing, adaptation, distribution and reproduction in any medium or format, as long as you give appropriate credit to the original author(s) and the source, provide a link to the Creative Commons licence and indicate if changes were made.

The images or other third party material in this chapter are included in the chapter's Creative Commons licence, unless indicated otherwise in a credit line to the material. If material is not included in the chapter's Creative Commons licence and your intended use is not permitted by statutory regulation or exceeds the permitted use, you will need to obtain permission directly from the copyright holder.

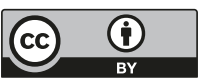

